\title{
POTENSI ARKEOLOGI DI GUA-GUA SEKITAR SONG PEDANG, KABUPATEN GUNUNG KIDUL
}

\author{
(The Archaeological Potential Of Caves Around Song Pedang, Gunung Kidul)
}

\section{Rizka Purnamasari}

Balai Arkeologi Provinsi D.I. Yogyakarta

Jl. Gedongkuning, No. 174, Yogyakarta 55171

Pos-el: songpedang@gmail.com

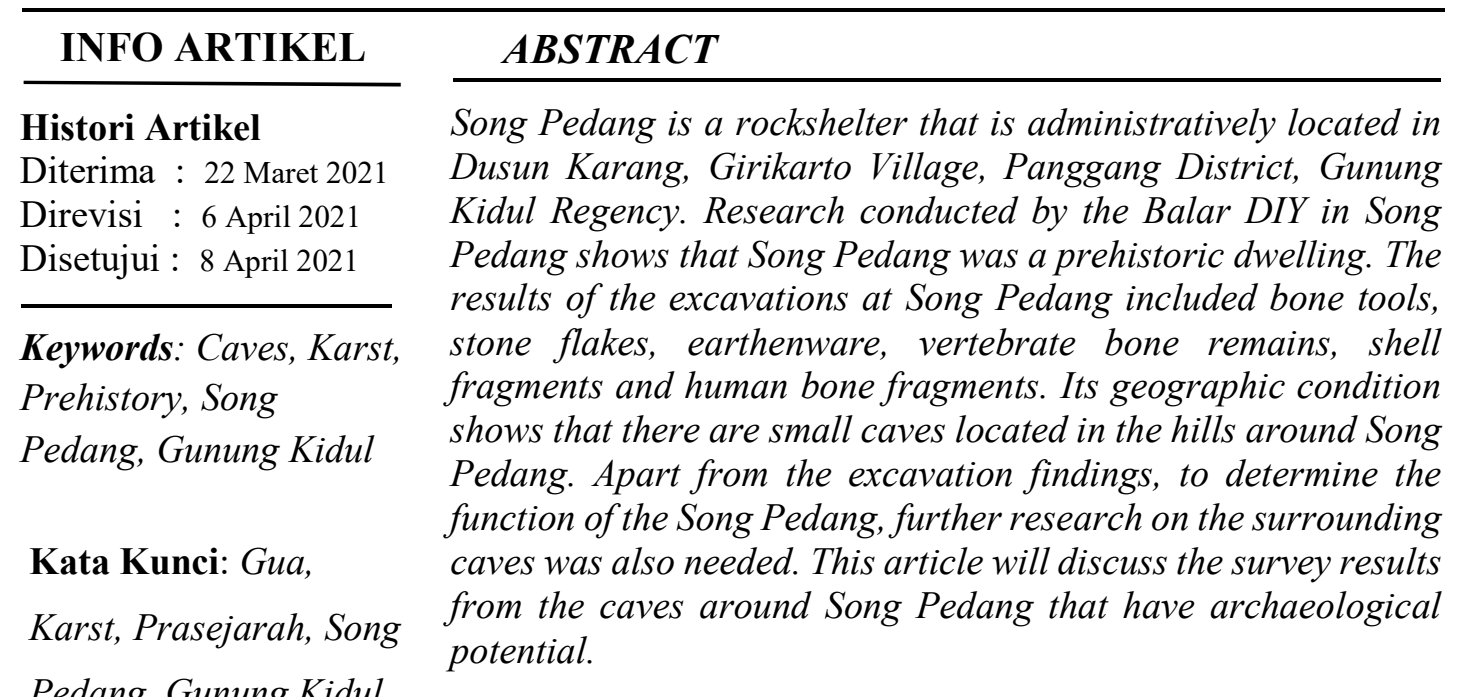

\footnotetext{
ABSTRAK

Song Pedang merupakan sebuah ceruk yang secara administratif terletak di Dusun Karang, Desa Girikarto, Kecamatan Panggang, Kabupaten Gunung Kidul. Penelitian yang dilakukan oleh Balai Arkeologi Provinsi DIY di Song Pedang menunjukkan bahwa Song Pedang merupakan hunian pada Masa Prasejarah. Hasil temuan ekskavasi di Song Pedang diantaranya adalah alat tulang, serpih batu, gerabah, sisa-sisa tulang vertebrata, fragmenfragmen cangkang kerang dan fragmen-fragmen tulang manusia. Kondisi geografisnya menunjukkan bahwa terdapat gua-gua kecil yang terletak pada bukit-bukit di sekitar Song Pedang. Selain dari temuan ekskavasi, untuk menentukan fungsi dari Song Pedang juga diperlukan penelitian lebih lanjut pada guagua di sekitarnya. Artikel ini akan membahas hasil survei dari gua-gua di sekitar Song Pedang yang memiliki potensi arkeologis
} 


\section{PENDAHULUAN}

Tidak dapat dipungkiri jika wilayah karst Gunung Sewu menyimpan cerita yang menarik dan penting mengenai kehidupan prasejarah. Bentukan perbukitan karst yang membentang dari wilayah Kabupaten Gunung Kidul di Daerah Istimewa Yogyakarta, hingga Wonogiri di Provinsi Jawa Tengah dan berakhir di Pacitan, Provinsi Jawa Timur menyimpan situs-situs arkeologi yang menciptakan sebuah kerangka hunian yang panjang pada masa prasejarah di wilayah ini.

Balai Arkeologi D.I. Yogyakarta pada tahun 2013 dan 2014 telah melakukan penelitian berupa survei untuk mengetahui potensipotensi arkeologi dari gua-gua di Gunung Sewu Bagian Barat. Survei dilakukan di wilayah tiga kecamatan di Gunung Kidul, meliputi Saptosari, Panggang dan Purwosari (Alifah et al., 2013, 2014). Dari 89 gua dan ceruk yang berhasil disurvei terdapat sekiranya 36 gua dan ceruk yang berpotensi menjadi hunian pada masa prasejarah (Alifah et al., 2014). Dari 36 gua dan ceruk tersebut setidaknya ditemukan beberapa temuan baik dari permukaan maupun test pit seperti fragmen gerabah, fragmen tulang dan gigi hewan, fragmen kerang darat maupun laut, kulit kemiri, arang, alat kerang dan tatal batu (Alifah et al., 2014).

Sebagai tindak lanjut dari hasil penelitian sebelumnya, pada tahun 2019 tepatnya di bulan Juli-Agustus Balar DIY melakukan penelitian yang berjudul "Strategi Subsistensi Pada Masa Prasejarah Di Gua-Gua Gunung Sewu Bagian Barat: Sebuah Pendekatan Zooarchaeology". Penelitian ini berupa ekskavasi dan survei arkeologi. Lokasi yang dipilih untuk diekskavasi adalah sebuah ceruk bernama Song Pedang. Song Pedang dinilai memiliki kriteria sebuah hunian. Temuan tes pit di Song Pedang diantaranya adalah fragmen gerabah, cangkang kerang, fragmen kepiting, fragmen tulang binatang, dan alat batu. Secara morfologis gua ini berpotensi menjadi hunian, dekat dengan sumber air dan berjarak sekitar 2,6 km dari garis pantai.

Secara administratif Song Pedang masuk ke dalam wilayah Dusun Karang, Desa Girikarto, Kecamatan Panggang, Kabupaten Gunung Kidul pada koordinat S $08^{0} 04^{\prime} 33.25 "$ dan E $110^{0} 26^{\prime} 12.78$ " dengan ketinggian 214 mdpl dan menghadap ke selatan. Lokasi 
Song Pedang termasuk mudah ditemukan karena letaknya dekat dengan jalan utama menuju Pantai Grigak. Lokasi ini dapat ditempuh dengan kendaraan seperti mobil dan sepeda motor. Denah lokasi Song Pedang dapat dilihat pada Gambar 1.

Song Pedang ini merupakan ceruk yang terletak pada sebuah bukit yang bagian depannya dimanfaatkan sebagai lahan pertanian yang mayoritas terdiri dari tanaman kebun seperti ketela, tembakau dan cabai. Dalam kesehariannya Song Pedang digunakan sebagai tempat untuk menyimpan alatalat yang bermanfaat untuk kegiatan pengolahan kebun. Secara kepemilikan Song Pedang masuk ke dalam lahan dari salah seorang warga Desa Girikarto yang bernama Bapak Tuyadi Utomo (Taniardi et al., 2019).

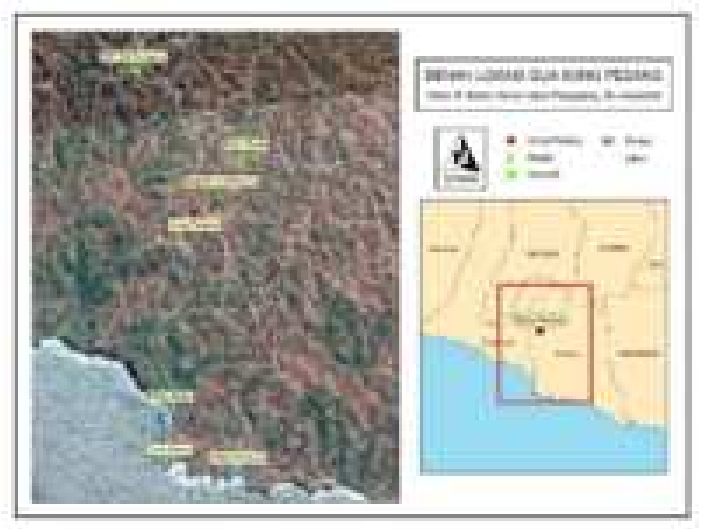

Gambar 1. Denah lokasi Song Pedang, Gunung Kidul (Sumber: Balar Prov. DIY)
Ekskavasi di Song Pedang dilakukan dengan membuka dua kotak galian test pit berukuran 1 x $1 \mathrm{~m}$. Ekskavasi ini bersifat trial excavation yang bertujuan untuk menjajagi lebih dalam lagi mengenai potensi arkeologi di Song Pedang. Artefak yang ditemukan di Song Pedang mayoritas adalah alat-alat tulang, meskipun ditemukan juga serpihan yang diduga merupakan sisa dari pembuatan alat batu. Pada lapisan-lapisan awal ditemukan juga beberapa fragmen gerabah yang diduga dari lapisan budaya sekarang (resen). Jenis-jenis alat tulang yang ditemukan di Song Pedang ada 2 jenis, yaitu lancipan dan spatula. Mayoritas lancipannya berukuran kecil dan terbuat dari hewanhewan seperti Macaca sp. (monyet) yang pada masa lalu sangat mudah dijumpai di wilayah karst Gunung Sewu. Macaca sp. merupakan sisa fauna yang sangat banyak ditemukan di situs-situs gua prasejarah di Gunung Sewu seperti di Song Keplek, Gua Braholo (Prasetyo, 2004, 147), Song Terus (Kusno, 2009, 22), dan Song Tritis (Riani, 2007, 23). 


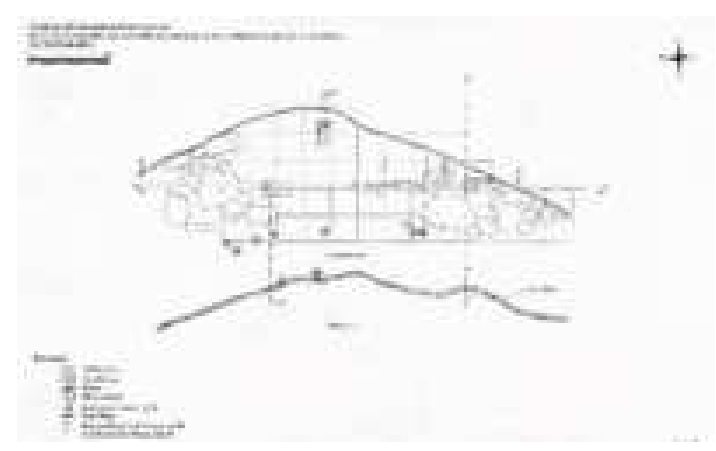

Gambar 2. Denah kotak ekskavasi Song Pedang, Gunung Kidul (Sumber: Balar Prov. DIY)

Ekofak yang ditemukan di Song Pedang dibagi menjadi tiga jenis, yaitu tulang-tulang fauna vertebrata, fauna avertebrata dan tulang manusia. Fragmen tulang yang berhasil diidentifikasi berasal dari fauna dalam genus Cercopithecidae, Felidae, Canidae Suidae, Bovidae, Muridae, Hystricidae, Cervidae, Viverridae, Hylobatidae, Trachypithecus, Carcharhinidae, Sciuridae, dan Veneridae (Taniardi et al. 2019, 56). Fragmen tulang maupun gigi dari Macaca $s p$ sangat mendominasi jenis temuan fauna vertebrata di Song Pedang.

Fragmen cangkang kerang yang ditemukan pada kotak TP 1 secara umum terdiri dari dua jenis yakni Gastropoda dan Bivalvia. Beberapa kerang yang dapat diidentifikasi diantaranya adalah dari keluarga Mytilidae, Thiaridae, Neritidae,
Tonnidae, Donacidae, Patellidae, Trochidae, Helicarionidae, Camaenidae dan Chiton (Taniardi et al. 2019, 56). Termasuk di dalam fragmen cangkang kerang adalah fragmen biota laut lainnya sepert tulang ikan, teritip, dan landak laut. Selanjutnya, identifikasi gigi dan fragmen tulang pipih yang ditemukan pada spit 15 dan 17 menunjukkan bahwa fragmen tersebut berasal dari individu Homo sapiens dewasa.

Hasil penelitian pada tahun 2019 menunjukkan bahwa Song Pedang merupakan sebuah hunian pada masa prasejarah. Hal ini mendukung dugaan awal pada survei tahun 2013 yang menjadikan Song Pedang sebagai salah satu gua dengan potensi arkeologi yang berdasarkan dari bentuk morfologi gua, hasil test pit dan lokasinya yang dekat dengan sumber air (Alifah et al., 2013). Namun demikian masih perlu dilakukan penelitian lebih lanjut di Song Pedang untuk mengetahui fungsinya di masa lalu, apakah sebagai shelter perburuan, ataukah hunian tetap.

Sofian (2011) pernah membahas mengenai pola sebaran gua dan ceruk yang berpotensi sebagai hunian masa lalu di Kecamatan Paliyan, Gunungkidul. Penelitian ini 
menggunakan Analisis Tetangga Terdekat (Nearest Neighbour Analysis) secara manual dan dilengkapi dengan Analisis Tetangga Terdekat yang ada pada perangkat lunak Arc View. Hasil dari penelitian ini adalah pembagian gua-gua arkeologis di Paliyan menjadi 4 kelompok berdasarkan wilayah geografisnya. Penelitian ini juga memberikan informasi mengenai gua mana saja di Paliyan yang berpotensi menjadi hunian tetap maupun sementara, dilihat dari ukuran dan morfologi gua (Sofian 2007, 122-134).

Yuwono (2009) meneliti mengenai interaksi pesisir dan pedalaman pada Kala Akhir Pleistosen hingga Pertengahan Holosen di wilayah karst Gunung Sewu. Dalam artikelnya diperoleh kesimpulan mengenai pola distribusi linear pada situs gua memperlihatkan bahwa penghunian gua di Gunung Sewu dipengaruhi oleh medan dan unsur-unsur paleolandscape. Koridor lembah kars menentukan oleh interaksi antar komunitas dalam wilayah geografis yang berbeda (Yuwono 2009, 33-44).

Sebaran gua dan ceruk di sekitar Song Pedang merupakan aspek yang perlu diperhatikan untuk menjawab pertanyaan mengenai fungsi dari Song
Pedang itu sendiri, selain dilihat dari ragam artefak dan ekofaknya. Sebaransebaran ini merupakan bagian dari kondisi geografis yang mempengaruhi bagaimana manusia beradaptasi dengan lingkungannya, khususnya dalam hal pemilihan penggunaan sebuah ceruk ataupun gua.

\section{METODE}

Untuk melengkapi data mengenai potensi arkeologi di wilayah ini, survei arkeologi dilakukan di beberapa gua di sekitar Song Pedang. Beberapa gua yang sudah tercatat pada survei tahun 2014 diuji coba dengan pembukaan test pit. Pada saat survei ditemukan pula sejumlah gua baru yang potensial, namun ada pula yang sebenarnya potensial namun sudah terkontaminasi oleh adanya penambangan fosfat yang dilakukan

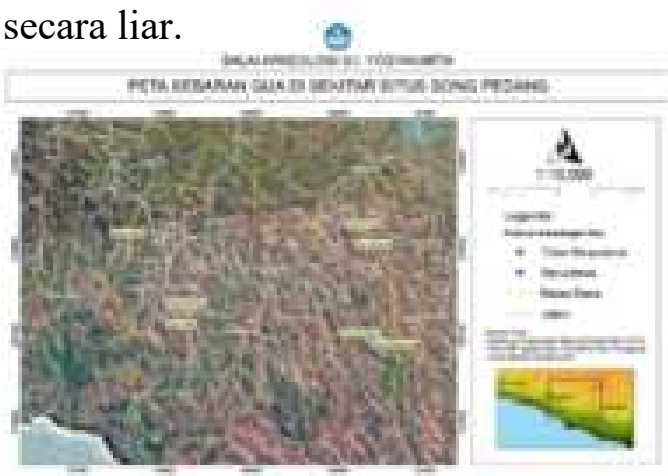

Gambar 3. Peta Sebaran Gua di Sekitar Song Pedang, Gunung Kidul (Sumber: Balar Prov. DIY) 
Penentuan jalur dan lokasi survei dipilih dengan menggabungkan informasi yang ada pada Laporan Penelitian Balai Arkeologi DIY yang berjudul Potensi Arkeologi Gua-Gua di Kawasan Gunung Sewu Bagian Barat Tahap II (Alifah et al., 2014) dan informasi dari warga setempat. Setelah menggabungkan dua sumber tersebut ditentukan titik-titik yang menjadi tujuan survei, yaitu Song Rene, Gua Jotak, Goa Suruh, Goa Jepang, Goa Ngasinan dan Goa Kedokan. Namun yang akan dibahas pada artikel ini hanyalah beberapa gua yang masih memiliki kemungkinan yang besar untuk diteliti.

\section{HASIL DAN PEMBAHASAN}

Terdapat tiga gua yang berpotensi arkeologi di sekitar Song Pedang yang berhasil disurvei oleh tim. Hasil ini diperoleh dari pertimbangan morfologi gua, temuan permukaan maupun test pit dan morfologi lingkungan di sekitar gua. Berikut merupakan deskripsi dari gua-gua tersebut.

\section{Song Rene}

Secara administratif Song Rene masuk dalam wilayah Desa Giriwungu dengan koordinat $\mathrm{S} 08^{\circ} 04^{\prime} 07.02^{\prime \prime}$ dan E $110^{\circ} \quad 25^{\prime} 51.33^{\prime \prime}$ serta memiliki ketinggiannya $198 \mathrm{~m}$ dpl. Gua ini juga terletak pada sebuah bukit yang di sekelilingnya dimanfaatkan sebagai lahan pertanian dengan mayoritas tanamannya adalah ketela pohon dan kelapa.

Jarak Song Rene dan Song Pedang diperkirakan $\pm 2,6 \mathrm{~km}$ jika menggunakan jalur jalan utamanya. Jika mengambil jalur hutan dan lahan pertanian, untuk sampai ke Song Rene dari Song Pedang akan melewati jalurjalur pendek yang saling menyambung di antara bukit-bukit kecil. Kemiringan medan yang dilewati tidak terlalu sulit.

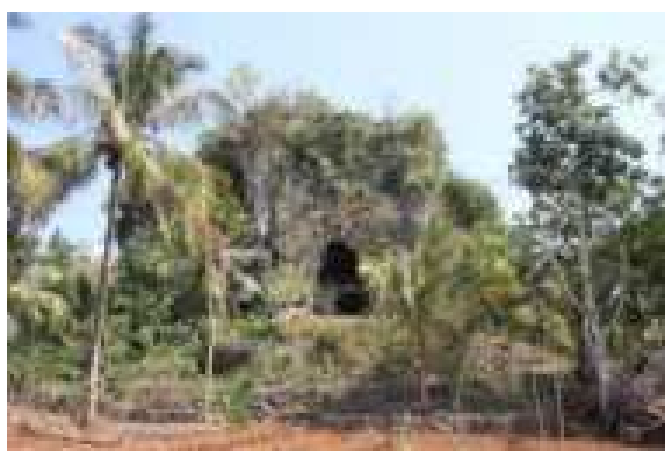

Gambar 4. Song Rene tampak depan (Sumber: Balar Prov. DIY)

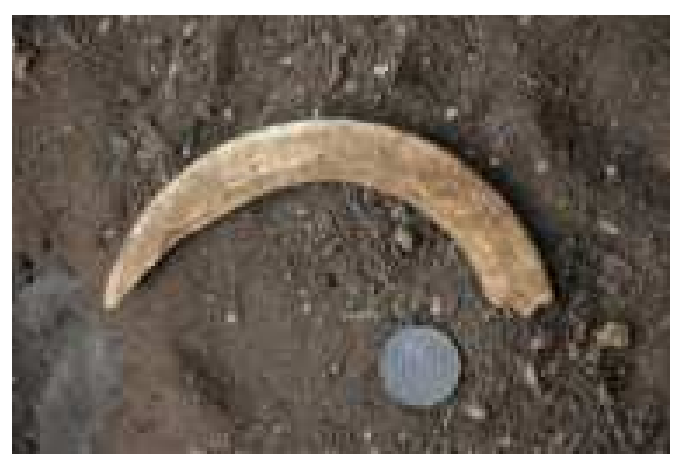

Gambar 5. Taring babi hutan (Sumber: Balar Prov. DIY) 


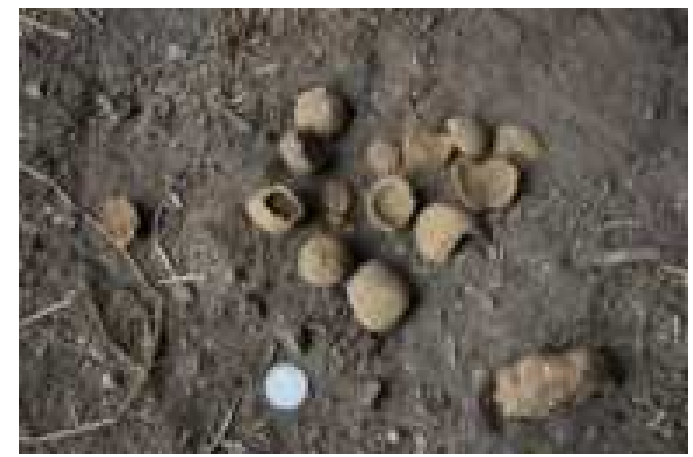

Gambar 6. Fragmen kulit kemiri

(Sumber: Balar Prov. DIY)

Beberapa temuan permukaan yang dapat dijumpai adalah fragmen kerang laut, fragmen siput darat dan siung babi hutan. Kebanyakan temuan permukaan justru ditemukan di bagian luar mulut gua tetapi di pojok, di lokasi yang kurang terjamah oleh manusia. Untuk menjajaki potensi arkeologis, sebuah kotak test pit dengan luas $50 \mathrm{~cm}$ x $50 \mathrm{~cm}$ digali di bagian tengah gua. Temuan test pit mayoritas berupa arang, kulit kemiri dan sejumlah cangkang gastropoda terrestrial. Kemungkinan besar arang yang ada merupakan sisasisa kegiatan manusia yang tergolong baru. Saat ini Song Rene dimanfaatkan sebagai tempat berteduh dan tempat menyimpan alat-alat atau hasil dari lahan bercocok tanam.

Di sisi barat Song Rene ditemukan gua yang sebenarnya masih terdapat di bukit yang sama. Kalau dilihat dari depan, gua ini tidak akan terlihat. Untuk sampai ke gua ini harus berjalan ke arah barat dan menaiki bukit karena letaknya berada di atas dan cukup tinggi. Gua ini jarang atau hampir tidak pernah terjamah kegiatan manusia di masa sekarang. Beberapa temuan permukaan seperti kulit kemiri, tulang-tulang vertebrae dari hewanhewan berukuran sedang, fragmen kerang laut berukuran sedang dan tulang panjang tikus dapat dijumpai di sini. Adanya kulit kemiri di tempat tinggi seperti ini memang tidak selalu merupakan sisa kegiatan manusia, bisa saja dibawa oleh kera ekor panjang yang memang mudah dijumpai di daerah ini setidaknya hingga 20 tahun yang lalu.

Meskipun untuk sampai ke gua ini cukup membutuhkan usaha lebih, tetapi ada satu hal menarik dari letaknya. Gua ini memiliki dua entrance di bagian barat daya dan bagian barat, dari entrance bagian barat kita bisa melihat ke seluruh lembah dengan jangkauan pandang yang luas. Jika diasumsikan maka tempat ini cukup sesuai menjadi tempat untuk mengintai mangsa dalam berburu. Bisa jadi tempat ini tidak difungsikan sebagai tempat tinggal, namun semacam base camp untuk berburu dalam kaitannya sebagai tempat 
mengintai mangsa (bukan base camp untuk menjagal hasil buruan). Perlu dilakukan penelitian lebih jauh lagi untuk dapat mengetahui fungsi gua ini.

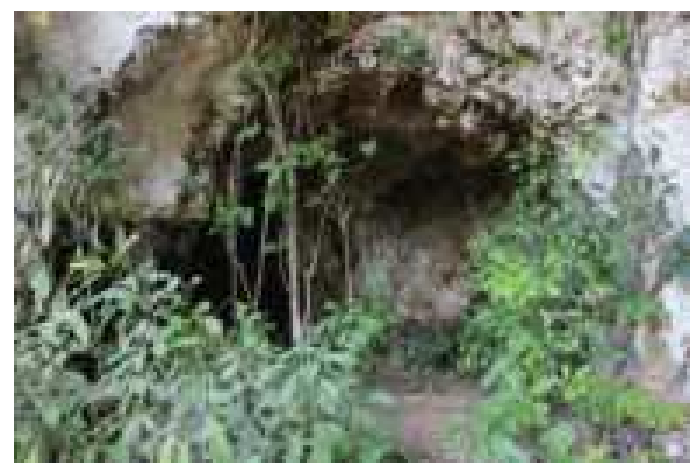

Gambar 7. Song Rene II dari pintu sebelah barat daya

(Sumber: Balar Prov. DIY)

\section{Gua Suruh}

Gua Suruh terletak pada koordinat S $08^{\circ} 04^{\prime} 04.58^{\prime \prime}$ dan E $110^{\circ}$ 27'21.25" serta memiliki ketinggian 242 m dpl. Jika diukur melalui jalur utama, jarak Gua Suruh sekitar 3,4 km dari Song Pedang. Untuk menuju ke Gua Suruh dari Song Pedang pada masa lalu akan cukup memakan waktu, karena harus melewati lembah-lembah pendek yang mengitari bukit-bukit di sepanjang lingkungan itu.

Letak Gua Suruh agak tinggi dan harus memanjat sedikit meskipun tidak terlalu sulit. Pada bagian depan Gua Suruh adalah sebuah bukit yang melindungi dan menutupi Gua Suruh dari arah utara. Gua ini memiliki aliran air (tetesan) yang kecil di bagian dalam, namun keadaannya tidak terlalu lembab. Test pit berukuran $50 \mathrm{~cm}$ x 50 cm pun dilakukan pada Gua ini di sisi bagian dalam sebelah selatan dan menempel pada dinding gua bagian dalam. Hasil temuannya berupa fragmen rahang bawah Macaca sp., fragmen kerang laut, fragmen siput darat dan sebuah batu yang diperkirakan merupakan alat karena memiliki pangkasan dan bekas pengasahan yang terlihat jelas.

Dilihat dari lingkungan dan hasil test pit Gua Suruh berpotensi menjadi gua hunian yang utama (main camp). Karena posisinya di balik bukit yang terlindung dari pandangan musuh atau predator dari arah utara. Letaknya yang menjorok dan menempel pada sebuah bukit juga membuat wujud guanya tidak terlalu terlihat dari arah barat. Akses utama menuju Gua ini memang berada di bagian barat.

Sinar matahari di Gua ini cukup dan malah cenderung nyaman karena tidak terpapar secara langsung oleh matahari. Sirkulasi udara bagus, karena gua ini memiliki semacam ruang lagi yang tembus keluar di bagian dalam dan lubang menuju ruang tersebut agak berfungsi sebagai ventilasi. Dari kadar tetesan air yang kecil, dipadukan 
dengan sinar matahari yang cukup, serta adanya lubang ventilasi menyebabkan gua ini menjadi tidak terlalu lembab.

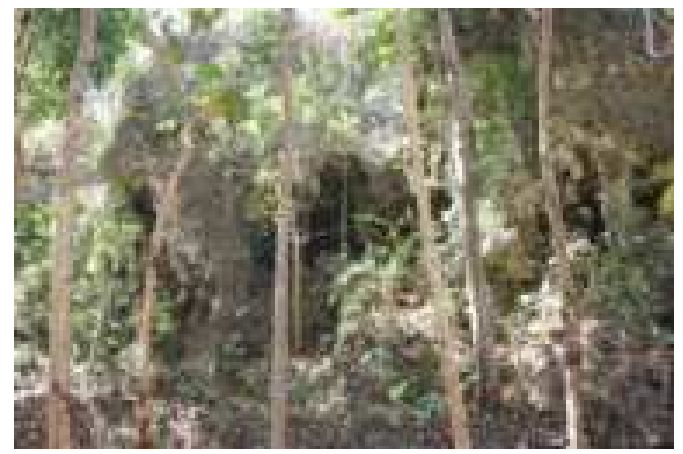

Gambar 8. Bagian depan Gua Suruh (Sumber: Balar Prov. DIY)

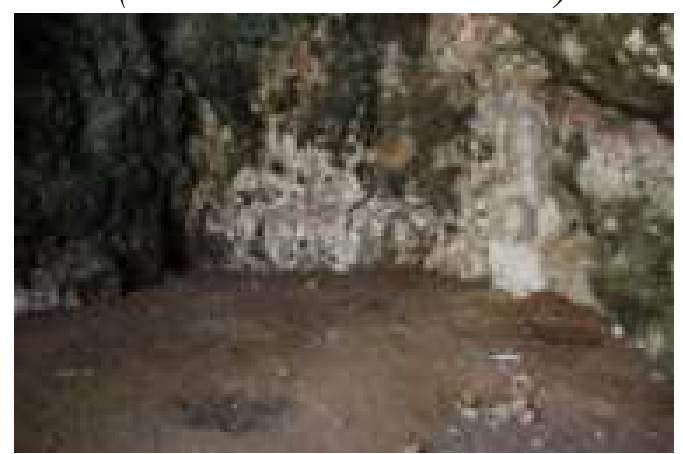

Gambar 9. Bagian dalam Gua Suruh dan lokasi test pit

(Sumber: Balar Prov. DIY)

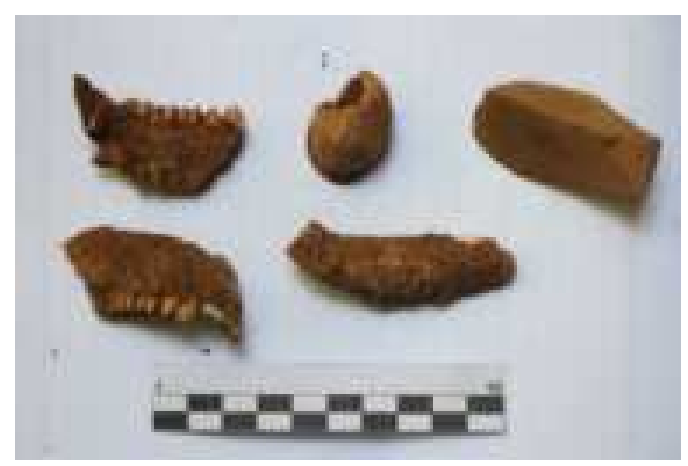

Gambar 10. Temuan test pit Gua Suruh pada kedalaman $1-5 \mathrm{~cm}$ (Sumber: Balar Prov. DIY)

\section{Goa Ngasinan}

Gua Ngasinan terletak jauh ke dalam wilayah hutan dan lahan warga, koordinatnya adalah S 0804'49.03" dan $\mathrm{E} 110^{\circ} 27^{\prime} 30.50^{\prime \prime}$ dengan ketinggian 195 m dpl. Gua ini juga terletak pada sebuah bukit dan harus mendaki sedikit untuk sampai ke mulut gua. Sebenarnya jika dilihat dari lingkungan dan bentuk fisik gua serta temuan kerang-kerang laut di bagian luar entrance, gua ini cukup potensial jika digunakan sebagai hunian utama (main camp). Tetapi sayangnya di beberapa titik terdapat bekas-bekas penggalian untuk pencarian fosfat.

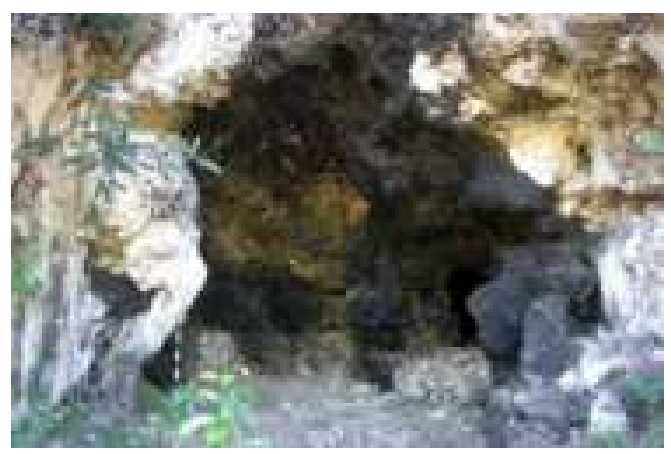

Gambar 11. Bagian mulut Gua Ngasinan (Sumber: Balar Prov. DIY)

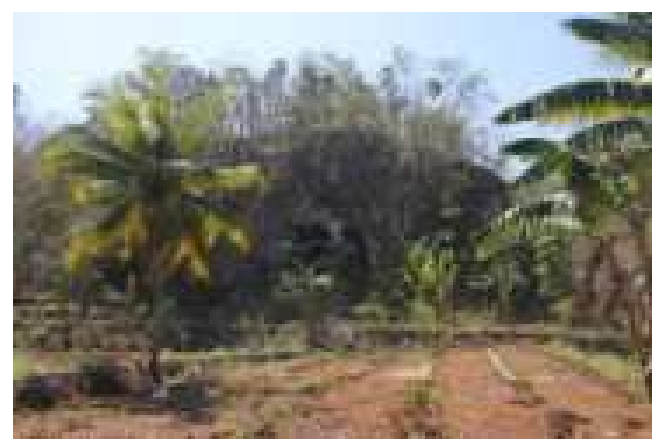

Gambar 12. Bagian depan Gua Ngasinan (Sumber: Balar Prov. DIY)

Selain dilihat dari ragam jenis artefak dan ekofaknya, untuk menentukan fungsi dari sebuah gua atau ceruk perlu juga untuk melihat 
lingkungan di sekitarnya. Morfologi pegununungan, baik itu area lembah, perbukitan, celah-celah kecil di antara perbukitan, serta keberadaan gua dan ceruk lain di sekitarnya merupakan hal yang perlu dijadikan pertimbangan.

Dalam studi keruangan dikenal tiga tingkatan, yaitu keruangan mikro, semi mikro dan makro. Keruangan mikro mempelajari tentang hubungan antar ruang dalam satu bangunan, sedangkan keruangan semi mikro mempelajari hubungan antar unit ruang yang dapat dikelompokkan dalam dalam satu komunitas atau situs (Nurani, 1997, 14-23). Lain halnya dnegan keruangan makro yang mempelajari hubungan antar situs yang meliputi beberapa komunitas dalam cakupan kawasan (Clarke, 1977 dalam Nurani 1997, 14-23). Lebih lanjut, penentuan fungsi sebuah gua atau ceruk harus melibatkan studi keruangan berskala makro.

\footnotetext{
Lebih jauh, Binford mengungkapkan bahwa untuk mengetahui tentang pola hidup yang dipakai pada masa lalu harus diawali dengan pengertian mengenai hubunganhubungan antar lokasi yang berbeda pemanfaatannya di masa lalu (Binford, 1982, 5-31).
}

Menurut Burns dan Rabber fungsi dari sebuah ceruk baik itu untuk base camp maupun logistical camp selalu menjadi perdebatan, namun ada beberapa hal yang harus diperhatikan juga untuk mengetahui fungsinya di antaranya adalah jumlah penghuni, komposisi sosial dari kelompok, penggunaan ruang, aktivitas manusia, musim, dan mobilitas kelompok. Sebuah ceruk dapat memiliki berbagai fungsi, tergantung kebutuhan dan strategi adaptasi penghuninya (Burns and Raber, 2010: 257-285). Fungsi-fungsi ini mungkin bergantung pula pada waktu atau tempat dengan perbedaan besar yang tercermin dari durasi okupasi dan skala geografisnya (Brush, Kardulias, and Donaldson, 2010: 305332).

$$
\text { Morfologi lingkungan }
$$
mendasari keputusan-keputusan manusia dalam memanfaatkan ceruk dihadapkan dengan kebutuhan dan strategi adaptasi mereka. Gua-gua dan ceruk di sekitar Song Pedang ini perlu dijadikan pertimbangan dalam menentukan fungsi Song Pedang itu sendiri. Saat ini banyak dilakukan penelitian yang mengembangkan kerangka geoarkeologi dan spasial untuk analisis dan interpretasi data 
arkeologi dalam konteks pemanfaatan gua dan ceruk. Penelitian-penelitian sebelumnya sangat bergantung pada karakteristik morfologi dan hasil ekskavasi untuk menentukan fungsi, sedangkan sekarang ini banyak penelitian mulai mengembangkan pendekatan multidisipliner yang mengintegrasikan makromorfologi, mikromorfologi dan analisis geokimia untuk menginterpretasi bentuk, fungsi dan pengaturannya (Homsey, 2010: 67).

\section{PENUTUP}

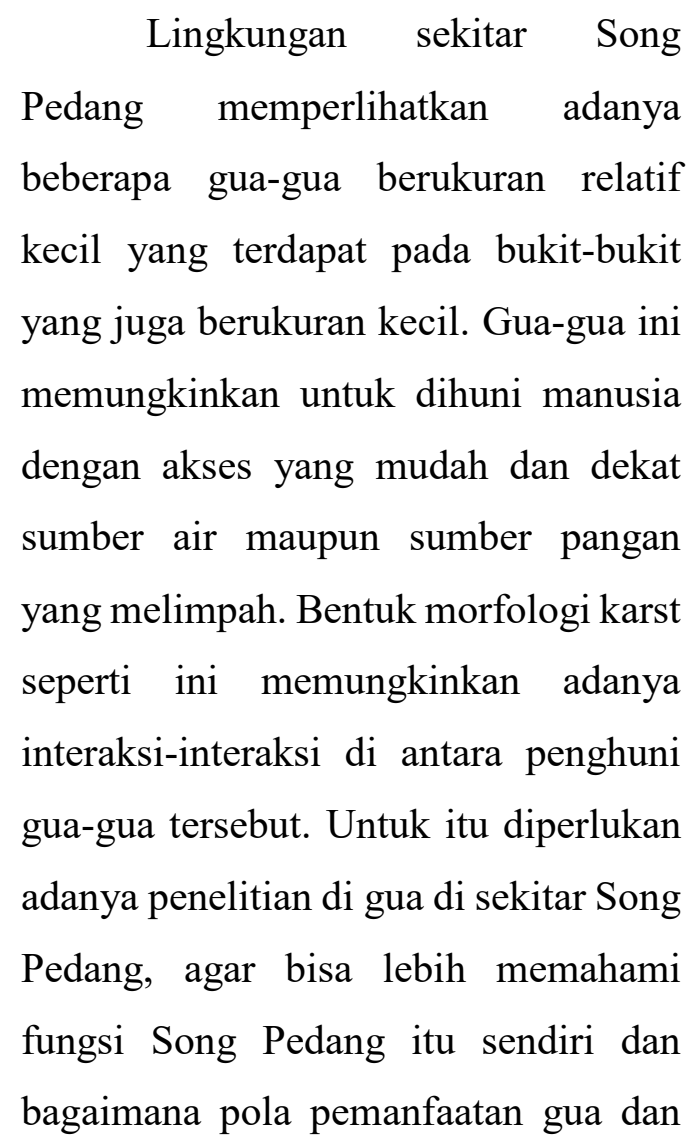

ceruk sebagai hunian pada Masa Prasejarah di wilayah Gunung Sewu Bagian Barat.

Sekitar tiga buah gua di sekitar Song Pedang memiliki potensi arkeologi yang bagus. Di antaranya adalah Song Rene, Gua Suruh dan Gua Ngasinan. Lokasi ini cocok untuk diteliti dilihat dari letak geografisnya, morfologi guanya hingga temuan permukaannya. Karakteristik gua di daerah ini yang memiliki ruang yang relatif kecil justru sangat menarik untuk diteliti pemanfaatannya. Manakah yang merupakan gua untuk hunian tetap dan mana yang digunakan sebagai hunian sementara. Pola interaksi antar gua juga dapat diketahui lebih jauh ketika menggabungkan fungsi-fungsi gua ini dan morfologi lingkungan di wilayah ini.

\section{Ucapan Terima Kasih}

Kepada seluruh pihak yang telah membantu penelitian ini kami sangat berterimakasih. Terutama untuk Fadly Ginanjar, Dedy Hariyansyah, Bayu Indra Saputro, Apriyatno, Bapak Sadiman, Bapak Tuyadi Utomo, Bapak Priyadi dan Bapak Kasiyo. 


\section{DAFTAR PUSTAKA}

Alifah, Gunadi, Nurani, I. A., Noerwidi, S., Sutiyanti, S., Taroreh, B., Mujiana, Suharmanto, Suhartatik, Sukarman, Azza, F., Yuwono, J. S. E., \& Riomandha, T. (2013). Laporan Penelitian Arkeologi, Potensi Arkeologi Gua-Gua di Kawasan Gunung Sewu Bagian Barat Tahap I (Kecamatan Saptosari).

Alifah, Gunadi, Siswanto, Noerwidi, S., Soesilo, H., Saputra, B. I., Bambang, Bakrun, Azza, F., A.H.P., N., \& Timotius. 2014. Laporan Penelitian Arkeologi, Potensi Arkeologi Gua-Gua di Kawasan Gunung Sewu Bagian Barat Tahap II (Kecamatan Panggang, Purwosari).

Binford, L. R. 1982. The Archaeology of Place. Journal Of Anthropological Archaeology, 31, 5-31.

Brush, N., Kardulias, P. N., \& Donaldson, S. 2010. The Facts and Fictions of Rockshelter Function. North American Archaeologist, 31(3), 305-332. https://doi.org/https://doi.org/10.2190\%2FNA.31.3-4.d

Burns, J. A., \& Raber, P. A. 2010. Rockshelters In Behavioral Context: Archaeological Perspectives From Eastern North America. North American Archaeologist, 31(3), 257-285. https://doi.org/10.2190/NA.31.3-4.b

Homsey, L. K. 2010. The Hunter-Gatherer Use of Caves and Rockshelters in the American Midsouth: A Geoarchaeological and Spatial Analysis of Archaeological Features at Dust Cave. BAR International Series.

Kusno, A. 2009. Archaeozoological contribution to the characterization of the stratigraphy of the Upper Pleistocene in Tabuhan layers (Song Terus Cave, Eastern Java, Indonesia). Muséum national d'Histoire naturelle.

Nurani, I. A. 1997. Pendekatan Keruangan dalam Kajian Permukiman Gua. Berkala Arkeologi, XVII(1), 14-23.

Prasetyo, B. 2004. Macaca sp. dan Hunian Gua. In T. Simanjuntak, R. Handini, \& B. Prasetyo (Eds.), Prasejarah Gunung Sewu (p. 147). Ikatan Ahli Arkeologi Indonesia.

Riani, R. I. 2007. Alat Tulang Situs Song Tritis, Kec. Rongkop, Kab. Gunung Kidul, Prop. D.I.Y : Tipologi, Teknologi, Dan Materi. Universitas Gadjah Mada.

Sofian, H. O. 2007. Sebaran Gua Arkeologis Di Kecamatan Paliyan Kabupaten 
Gunungkidul Dengan Menggunakan Analisis Tetangga Terdekat (Nearest Neighbourhood Analys). Berkala Arkeologi, 31(2), 122-134.

Taniardi, P. N., Purnamasari, R., Yudha, D. S., Darojah, C. I., Siswanto, Ananda, G. A. R., Abdurrahman, F., Marco, I., Nisa, Z., Ginanjar, F., Hariyansyah, D., Saputro, B. I., Riyanto, S., Sadiman, \& Apriyatno. 2019. Strategi Subsistensi Pada Masa Prasejarah Di Gua-Gua Gunung Sewu Bagian Barat: Sebuah Pendekatan Zooarchaeology.

Yuwono, J. S. E. 2009. Late Pleistocene To Mid-Holocene Coastal and Inland Interaction in the Gunung Sewu Karst, Yogyakarta. Bulletin of the Indo-Pacific Prehistory Association, 29(0), 33-44. https://doi.org/10.7152/bippa.v29i0.9475 